\title{
Clinical reliability of zirconium abutment in implant restorations in the English and Korean literature
}

\author{
Su-Been $\mathrm{Yu}^{1,2,3,4 \dagger}$, Bong-Gyu Song ${ }^{5 \dagger}$, Kyeong-Jun Cheon ${ }^{1,2}$, Ju-Won Kim ${ }^{1,2,3}$, Young-Hee Kim² \\ and Byoung-Eun Yang $1,2,3,6^{*}$
}

\begin{abstract}
Background: This study aimed to evaluate the mechanical, biological, and esthetic stability of a zirconium abutment according to evidence-based dentistry.

Main text: An electronic search was performed. Domestic studies were found using the keywords "zirconia abutments" and "zirconium abutment" in KMbase, KoreaMed, and the National Assembly Library, and international studies were found using the same keywords in PubMed. All identified studies were divided by evidence level from the viewpoint of the research type utilizing the evidence-based review manual. A total of 102 domestic studies (with Korean language) were found, and 9 of these studies were selected. In these nine studies, 3 had evidence level 3 and 6 had evidence level 4. A total of 97 international studies (with English language) were found, and 19 were selected. Among these 19 studies, 5 had evidence level 2 and 7 had evidence level 3, whereas the remainder had evidence level 4. According to the studies, zirconium abutments are mechanically, biologically, and esthetically stable, but the evidence level of these studies is low, and the follow-up duration is no longer than 5 years.

Conclusions: All examined studies verified the mechanical stability of zirconium abutments for a period no longer than 5 years. Therefore, a long-term clinical observation is needed. Zirconium abutments are thought to be biologically stable, but they are not superior to titanium abutments. As the esthetic stability of such abutments had a low evidence level in the studies that examined here, a much higher evidence level is needed.
\end{abstract}

Keywords: Zirconium abutment, Dental implant

\section{Introduction}

As the interest in the esthetic aspect of implant prosthesis increases, the importance of the esthetic element has been emphasized. It has been reported that ready-made titanium abutments leave a gray shade if the soft tissue is thin or if the gingival sulcus is shallow, and a non-esthetic outcome may be caused by the exposure of titanium in the gingival margin when a gingival recession occurs [1]. Alumina ceramic abutments have been developed to overcome the non-esthetic problem, but failed due to fracture

\footnotetext{
* Correspondence: omsyang@gmail.com

+ Su-Been Yu and Bong-Gyu Song contributed equally to this work.

${ }^{1}$ Department of Oral and Maxillofacial Surgery, Hallym University Sacred

Heart Hospital, Anyang, South Korea

2Department of Oral Implantology, Graduate School of Clinical Dentistry,

Hallym University, Chuncheon, South Korea

Full list of author information is available at the end of the article
}

caused by the brittleness of the alumina ceramic during functioning was reported. Since then, zirconium with high biological stability, an esthetic feature, and high mechanical stability has been used as an abutment [1]. According to the 2011 MFDS (Ministry of Food and Drug Safety, Republic of Korea) report, esthetic prosthetic treatment using zirconium prosthesis and implant abutment is on the spotlight, and over $12 \%$ of the high annual average growth rate has been shown in South Korea.

Zirconium abutments are widely used in South Korea, but it is not easy to find evidence of their clinical stability for long-term use by the Koreans. Glauser et al. reported that there was no fracture in the zirconium abutments in their study for an average of 49.2 months in single-tooth restoration [2]. Zembic et al. reported the long-term stability of zirconium abutments, showing a 
96.3\% success rate [3]. Additionally, the studies conducted by Canullo et al., Sailer et al., Zembic et al., and Nothdurft et al. reported a $100 \%$ success rate in zirconium abutment clinical practices [4-7]. All these studies, however, were conducted in Caucasian countries. Michael et al. reported that the maximum bite force was $725 \mathrm{~N}$, and the average masticatory force was $262 \mathrm{~N}$ in natural teeth [8]. Ferrario et al. reported that the maximum bite force was around $700 \mathrm{~N}$ in healthy adult males and females [9]. In Korean research, however, Cho reported that the maximum bite force was $923.8 \mathrm{~N}$ on average [10], and Yoon reported that the average bite force was $744.5 \mathrm{~N}$ [11]. Koreans who favor hard foods such as kimchi, gakdugi, squid, and ribs deliver a strong masticatory force to the molar area [12]. Kim et al. examined the subjective food intake ability of the maximum occlusal force among Korean adults [13]. Considering the difference in diet and bite force between the Koreans and Caucasians, the stability of zirconium needs to be evaluated in the Koreans and the evidence level must be established.

According to the Straumann report 2013, Korea is the country where dental implant treatment is most performed [14]. The Korean National Health Insurance Corporation announced that it would expand the coverage of dental implants in patients aged 70 and older beginning in 2015 and those aged 65 and older in 2016. Only patients older than 65 are eligible, but Korea is the second country to add implant treatment to the national health insurance after Sweden. However, the zirconium abutment was not included in the health insurance. We have reviewed the validity of zirconium abutment through Korean and English literature and wanted to provide a basis for its use. This study intended to help increase the treatment stability by offering evidence to the dentist's choice through the stability assessment of zirconium abutments, with a focus on evidence-based dentistry. The goal of this study is to review the status of clinical studies on the stability of zirconium abutments in papers in Korea and abroad and to refer to them for application in clinical medicine.

\section{Methods}

A key question was set. The significant element in determining the key question included the patient/problem (P), intervention (I), comparison (C), and outcome (O) (PICO). The combination of these four major elements is "PICO asking questions." According to PICO asking questions, "Does the zirconium abutment (P and I) have mechanical, biological, and esthetic stability $(\mathrm{O})$ compared to the titanium abutment $(\mathrm{C})$ ?" was set as a key question.

\section{Search strategy}

Literature was searched, using the keywords "zirconia abutment," or "zirconium abutment," in KoreaMed,
KMbase, and National Assembly Electronic Library, which were recommended as domestic literature search sites by $\lceil$ Evidence Literature Utilization Guidelines $\rfloor$ published by the Health Insurance Review and Assessment Service of Republic of Korea (2013a). Literature was searched using keywords including "zirconia abutment" and "zirconium abutment" in PubMed to compare the evidence levels of the stability of zirconium abutments in the domestic and international literature. The searched literature was selected by determining the inclusion and exclusion criteria based on the concept of evidence-based dentistry. The domestic literature included studies with Korean subjects and literature written in Korean. The scope of this study was clinical literature. Studies with international subjects, animal experiments, laboratory studies, expert commentaries, and scholarly literature were excluded.

\section{Stability assessment criteria and classification of the evidence level Stability assessment criteria}

In this literature, mechanical stability means that there are no problems of zirconium abutment fracture, abutment screw fracture, etc. To evaluate the biological stability, the conditions of the tissues around the zirconium abutments including the height of the bones, the plaque accumulation level in the soft tissue, the bleeding on probing, and the depth of the periodontal pocket were compared with the conditions of the tissues around the titanium abutments or around the healthy natural teeth. The esthetic stability was evaluated to be stable when the color and shape of the soft tissue surrounding the zirconium abutments were similar to those of the natural teeth.

\section{Classification of the study type according to the evidence level}

In this study, the grade criteria for clinical research literature suggested by the Health Insurance Review and Assessment Service were used. After the confirmation of the study type and contents that were selected based on Table 1, the evidence level was classified. According to the grade criteria for clinical research literature, the evidence level of

Table 1 Study type according to evidence level

\begin{tabular}{ll}
\hline Grade & Study type \\
\hline 1 (high) & $\begin{array}{l}\text { Systematic literature review targeting RCTs } \\
\text { (systematic review with/without meta-analysis) }\end{array}$ \\
2 & $\begin{array}{l}\text { Randomized controlled trial, systematic literature review } \\
\text { targeting category 3 }\end{array}$ \\
& $\begin{array}{l}\text { Quasi-RCT, cohort study, case-control study, } \\
\text { observational/analytic study }\end{array}$ \\
& $\begin{array}{l}\text { Cross-sectional study, case series, before/after study, } \\
\text { case report, non-analytic study }\end{array}$
\end{tabular}

Source: Health Insurance Review and Assessment Service. Republic of Korea, 2013a 
systematic literature review targeting randomized controlled trials (RCTs) is the highest, and the evidence level of cross-sectional study, case series, before/after study, case report, and non-analytic study is the lowest. As such, the lower the grade is, the higher the level of evidence.

\section{Main text}

As a result of the domestic literature search, a total of 102 kinds of literature were searched, including 28 kinds of literature at KoreaMed, 35 kinds of literature at KMbase, and 39 kinds of literature at the National Assembly Library. Of these 102 kinds of literature, 48 duplicate kinds of literature, 35 kinds of literature that fell under the exclusion criteria (including animal experiments and laboratory studies) based on a review of titles and abstracts, and three kinds of literature whose scope was not related to implant zirconium abutment were excluded. After a review of the full texts of the literature, six expert commentaries and one Master's thesis that was published in an international journal with a different title were excluded. Finally, nine literature were selected (Fig. 1).

International literature was searched at the Refomax Electronic Library of Hallym University Medical Center by linking with PubMed using keywords including "zirconium abutment" and "zirconia abutment." The literature type was set to review, clinical trial, and case report, and a total of 92 kinds of literature were selected: 13 reviews, 37 clinical trials, and 42 case reports. Based on the titles and abstracts, animal experiments, laboratory studies, and studies not related to implant zirconium abutment were excluded, and only the literature whose full texts could be obtained from the electronic library of the Hallym University Medical Center were selected. Finally, five reviews, eight clinical trials, and six case reports were selected (Fig. 2).

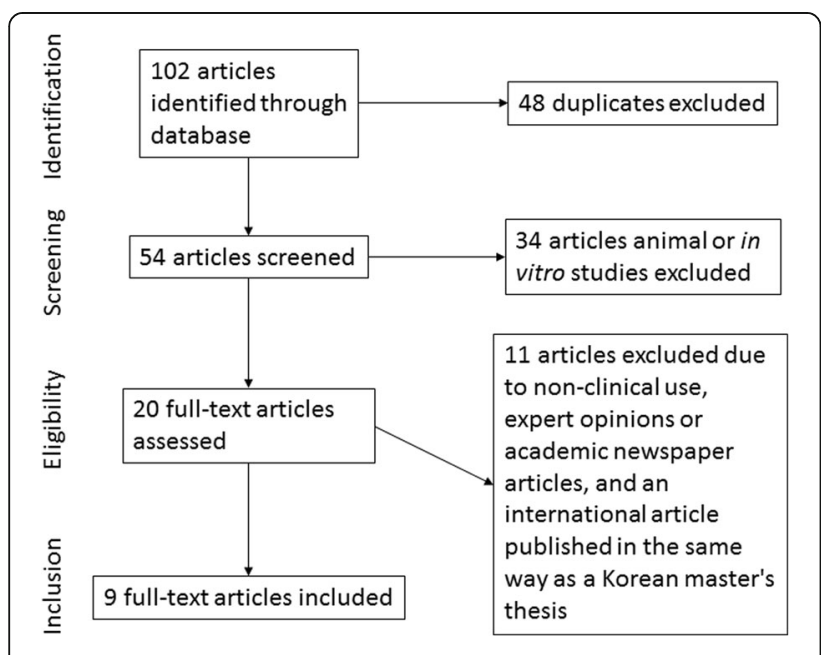

Fig. 1 The flow chart of the search strategy of the Korean literature

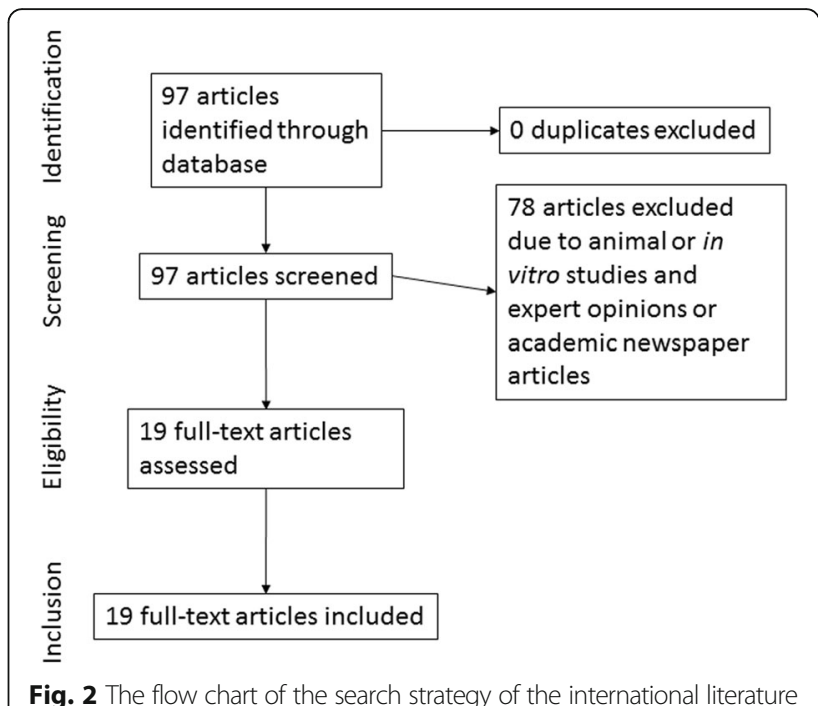

Fig. 2 The flow chart of the search strategy of the international literature

After the confirmation of the study types of the domestic and international literature, the evidence levels were classified. The classification results are presented in Table 2. For the domestic literature, there was no systematic literature review targeting RCTs, RCTs, and systematic literature reviews, which fall under evidence levels 1 and 2 , respectively. There were three cohort studies with evidence level 3, and 6 case reports with evidence level 4 .

In the international literature search process, there was a function for setting a literature type; thus, it was easy to classify the evidence level compared to the domestic literature search. About the evidence levels of international literature, there were five systematic literature reviews with evidence level 2, four cohort studies,

Table 2 Status of the evidence levels of domestic and international studies

\begin{tabular}{|c|c|c|c|}
\hline \multirow[t]{2}{*}{ Grade } & \multirow[t]{2}{*}{ Study type } & \multicolumn{2}{|c|}{ Result (literature) } \\
\hline & & Domestic & International \\
\hline 1 & $\begin{array}{l}\text { Systematic literature review targeting } \\
\text { RCTs (systematic review with/without } \\
\text { meta-analysis) }\end{array}$ & 0 & 0 \\
\hline \multirow[t]{2}{*}{2} & $\mathrm{RCT}$ & 0 & 0 \\
\hline & $\begin{array}{l}\text { Systematic literature review targeting } \\
\text { category } 3\end{array}$ & 0 & 5 \\
\hline \multirow[t]{4}{*}{3} & Quasi-RCT & 0 & 0 \\
\hline & Cohort study & 3 & 4 \\
\hline & Case-control study & 0 & 3 \\
\hline & Observational, analytic study & 0 & 0 \\
\hline \multirow[t]{4}{*}{4} & Cross-sectional study & 0 & 0 \\
\hline & Case series & 0 & 1 \\
\hline & Case report & 6 & 6 \\
\hline & Non-analytic study & 0 & 0 \\
\hline
\end{tabular}


and three case-control studies with evidence level 3, and 1 case series and 6 case reports with evidence level 4 .

\section{Domestic literature Evidence level 3}

A summary of three domestic kinds of literature with evidence level 3 is presented in Table 3. In the studies conducted by Kim et al., regarding the stability of zirconium abutments, the survival rate was high regardless of the implant location and prosthesis type, and the number of prosthesis units and prosthesis types appeared to be significantly associated with the complication rate of zirconium abutments [15]. Also, the zirconium abutments were mechanically stable within the 5-year follow-up period. Bae et al. reported that the zirconium abutments in their study were biologically stable [16].

\section{Evidence level 4}

A summary of six domestic kinds of literature with evidence level 4 is presented in Table 4. Evidence for the esthetic stability of zirconium abutments was shown in five kinds of literature out of six case reports with evidence level 4.

\section{International Literature Evidence level 2}

A summary of the outcomes of five international literature with evidence level 2 is presented in Table 5 . The stability evidence of zirconium abutments derived from the international literature with evidence level 2 can be roughly classified into two kinds. First, zirconium abutments are mechanically, biologically, and esthetically stable in general. In 16 literature evaluated by Medeiros et al. using the systematic literature review method [17], four literature evaluated by Guess et al. [18, 19], five literature evaluated by Gomes et al. [19], eight literature evaluated by Nakamura et al. [20], and one literature evaluated by Linkevicius et al. [21], the mechanical, biological, and esthetic stability of zirconium abutments was shown. The stability of zirconium abutments for long-term use, however, cannot be ensured. Medeiros et al. summarized 16 literature and revealed that the outcomes about the biological stability of zirconium abutments were varied [17]. Second, the stability of zirconium appeared to be positive within the short-term (4-year) clinical observation period. Four review literature, all reported that zirconium abutments are stable in the short term (within 5 years), but it is impossible to conclude the long-term stability of zirconium abutments due to the lack of long-term clinical studies.

\section{Evidence level 3}

In Table 6, the outcomes of seven international literature with evidence level 3 are summarized. The representative literature falling under evidence level 3 include cohort studies conducted by Zembic and Sailer $[3,6]$. The studies conducted by Zembic and Sailer reported the survival rate of the single crown using 20 titanium abutments and 20 zirconium abutments in 40 patients [3, 6]. Additionally, the probing pocket depth, plaque control record, bleeding on probing, and bone level on radiography were compared with those of the opposite tooth. The stability evidence of zirconium abutments derived from international literature with evidence level 3 is roughly classified into three kinds.

First, zirconium abutments are mechanically stable within the 3- and 5-year follow-up periods. This study emphasized that the average 5-year follow-up period is longer than the follow-up periods of other studies. Second, zirconium abutments are stable for the restoration of a single tooth in the anterior and premolar regions. In the study of Glauser et al., single crowns using 54 zirconium abutments were observed for 4 years, and mechanical problems such as abutment fracture and abutment screw fracture, and marginal bone loss, were examined. During the average 49.2-month follow-up period, abutment fracture did not occur, and the mean marginal bone loss was reported to be $1.2 \mathrm{~mm}$. Third, the esthetic stability of zirconium abutments cannot be determined [2]. Sailer et al. reported that there was no significant difference between zirconium and titanium abutments regarding their esthetic features. Fourth, zirconium abutments are biologically stable, but there is no significant difference between zirconium and titanium abutments regarding biological stability [6]. In the study of Van Brakel et al., in both zirconium and titanium, similar amounts of bacteria were detected, and the gingival health conditions were reported to be similar $[22,23]$. After designing an experiment as described above, Van Brakel performed the histological examination. In the 3-month histological examination, no statistically significant differences in the vascular density and the inflammation level were found [23].

\section{Evidence level 4}

In Table 7, the outcomes of seven international literature with evidence level 4 are summarized. The study object of all the literature with evidence level 4 is the maxillary anterior region.

The following three results were derived from international literature with evidence level 4. First, zirconium abutments are mechanically stable. In the study conducted by Lee et al., when nine patients were observed for 52 weeks after early loading, no abutment fracture or abutment screw loosening occurred [24]. Second, zirconium abutments are biologically stable. Aydin et al. reported that there was no difference in the probing pocket depth, plaque control record, bleeding on probing, and bone level on radiography at the soft tissue around the zirconium implant 6 months after the prosthesis installation 


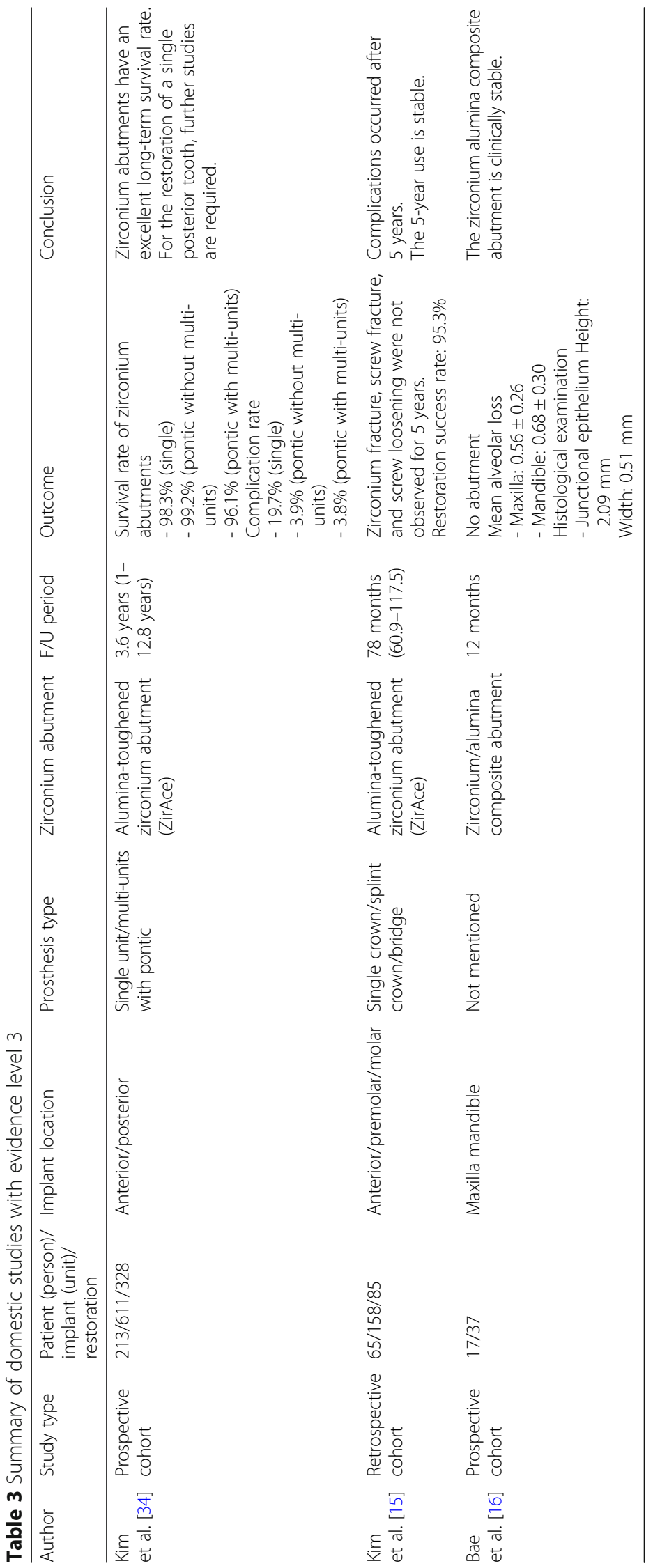


Table 4 Summary of domestic studies with evidence level 4

\begin{tabular}{|c|c|c|c|c|c|}
\hline Author & Study type & $\begin{array}{l}\text { Implant } \\
\text { location }\end{array}$ & Abutment & F/U period & Outcome \\
\hline \multirow[t]{3}{*}{ Kim et al. [35] } & Case report & $\# 11$ & Customized zirconium myplant & Not mentioned & $\begin{array}{l}\text { Interdental papillar } 100 \% \text { filled } \\
\text { The shape and the color are } \\
\text { harmonious. Functionally and } \\
\text { esthetically satisfactory }\end{array}$ \\
\hline & & \#21 & Customized zirconium myplant & 6 months & $\begin{array}{l}\text { Harmonious with the } \\
\text { adjacent teeth }\end{array}$ \\
\hline & & $\# 11$ & Customized zirconium myplant & Not mentioned & Not mentioned \\
\hline Byeon et al. [31] & Case report & $\# 21$ & Not mentioned & $\begin{array}{l}2 \text { months after installing } \\
\text { the prosthesis }\end{array}$ & Esthetic, oral hygiene maintained \\
\hline Lee et al. [32] & Case report & $\# 23$ & Customized zirconium abutment & $\begin{array}{l}6 \text { months after installing } \\
\text { the prosthesis }\end{array}$ & Stable \\
\hline Kim et al. [33] & Case report & $\begin{array}{l}\# 11 \\
\# 21\end{array}$ & $\begin{array}{l}\text { Ready-made zirconium } \\
\text { abutment (Osstem Korea) }\end{array}$ & $\begin{array}{l}10 \text { months after } \\
\text { treatment }\end{array}$ & Stable \\
\hline Byeon et al. [36] & Case report & $\# 11$ & Not mentioned & Not mentioned & Not mentioned \\
\hline Yun et al. [37] & Case report & \#21 & Not mentioned & Not mentioned & Esthetic, oral hygiene maintained \\
\hline
\end{tabular}

[25]. Third, zirconium abutments are generally esthetically stable. Kalman et al., Wadhwani et al., Mahn et al., and Schneider et al. reported the esthetic features in the maxillary anterior region [26-29]. However, Tan et al. reported that cast metal abutments have an excellent gingival contour and that zirconium abutment has an excellent gingival color when cast metal abutments are compared with ready-made zirconium abutments, indicating that zirconium abutments are not always superior to titanium abutments in terms of both the gingival contour and the color [30].

In this study, the domestic and international literature on the stability of zirconium abutments were analyzed, with a focus on evidence-based dentistry. As a result, the following shortcomings were shown.

First, the studies on the stability of zirconium abutments conducted for longer than 5 years are not sufficient. Considering that complications of zirconium

Table 5 Summary of international studies with evidence level 2

\begin{tabular}{|c|c|c|c|}
\hline Author & $\begin{array}{l}\text { No. of studies } \\
\text { (clinical studies) }\end{array}$ & Outcome & Conclusion \\
\hline $\begin{array}{l}\text { Medeiros } \\
\text { et al. [17] }\end{array}$ & 16 & $\begin{array}{l}\text { 1. The zirconium abutments showed excellent soft-tissue } \\
\text { reactions ( } 3 \text { studies). } \\
\text { 2. The gingival recession increased in the zirconium } \\
\text { abutments ( } 1 \text { study). } \\
\text { 3. No biological difference was observed between the } \\
\text { titanium and zirconium abutments ( } 9 \text { studies). } \\
\text { 4. The zirconium abutments provided the gingival contour } \\
\text { and anatomical shape of the natural teeth as well as } \\
\text { have excellent esthetic features ( } 3 \text { studies). }\end{array}$ & $\begin{array}{l}\text { 1. Zirconium abutments are recommended for the } \\
\text { anterior teeth. } \\
\text { 2. Long-term studies are required to evaluate biological } \\
\text { reactions. }\end{array}$ \\
\hline $\begin{array}{l}\text { Guess } \\
\text { et al. [18] }\end{array}$ & $18(4)$ & $\begin{array}{l}\text { The survival rate of the zirconium abutments was 100\% } \\
\text { (F/U period: } 6 \text { months-4 years). }\end{array}$ & $\begin{array}{l}\text { As there are limited clinical data on zirconium abutments, } \\
\text { their routine use in dental clinics is not recommended. }\end{array}$ \\
\hline $\begin{array}{l}\text { Gomes } \\
\text { et al. [19] }\end{array}$ & $20(5)$ & $\begin{array}{l}\text { 1. The survival rate of the zirconium abutments was good. } \\
\text { 2. The titanium abutments had more bone resorption } \\
\text { than the zirconium abutments. } \\
\text { 3. The zirconium abutments were esthetically and } \\
\text { functionally stable. } \\
\text { 4. No zirconium abutment fracture was observed for } \\
\text { four years. } \\
\text { 5. The zirconium abutments had less bacteria accumulation } \\
\text { than the titanium abutments. }\end{array}$ & $\begin{array}{l}\text { More studies on the long-term clinical success of } \\
\text { zirconium abutments are required. }\end{array}$ \\
\hline $\begin{array}{l}\text { Nakamura } \\
\text { et al. [20] }\end{array}$ & $25(8)$ & $\begin{array}{l}\text { 1. The zirconium abutments were acceptable for anterior } \\
\text { teeth in the biological and mechanical aspects. } \\
\text { 2. Zirconium had less early plaque accumulation than } \\
\text { titanium. }\end{array}$ & $\begin{array}{l}\text { The zirconium abutment has the potential to be used } \\
\text { as a dental implant abutment material. }\end{array}$ \\
\hline $\begin{array}{l}\text { Linkevicius } \\
\text { et al. [21] }\end{array}$ & $9(1)$ & $\begin{array}{l}\text { Titanium abutments do not maintain a higher bone level } \\
\text { than gold, aluminum oxide, and zirconium abutments. }\end{array}$ & $\begin{array}{l}\text { Due to the lack of clinical studies, the stability of } \\
\text { zirconium abutments cannot be determined. }\end{array}$ \\
\hline
\end{tabular}




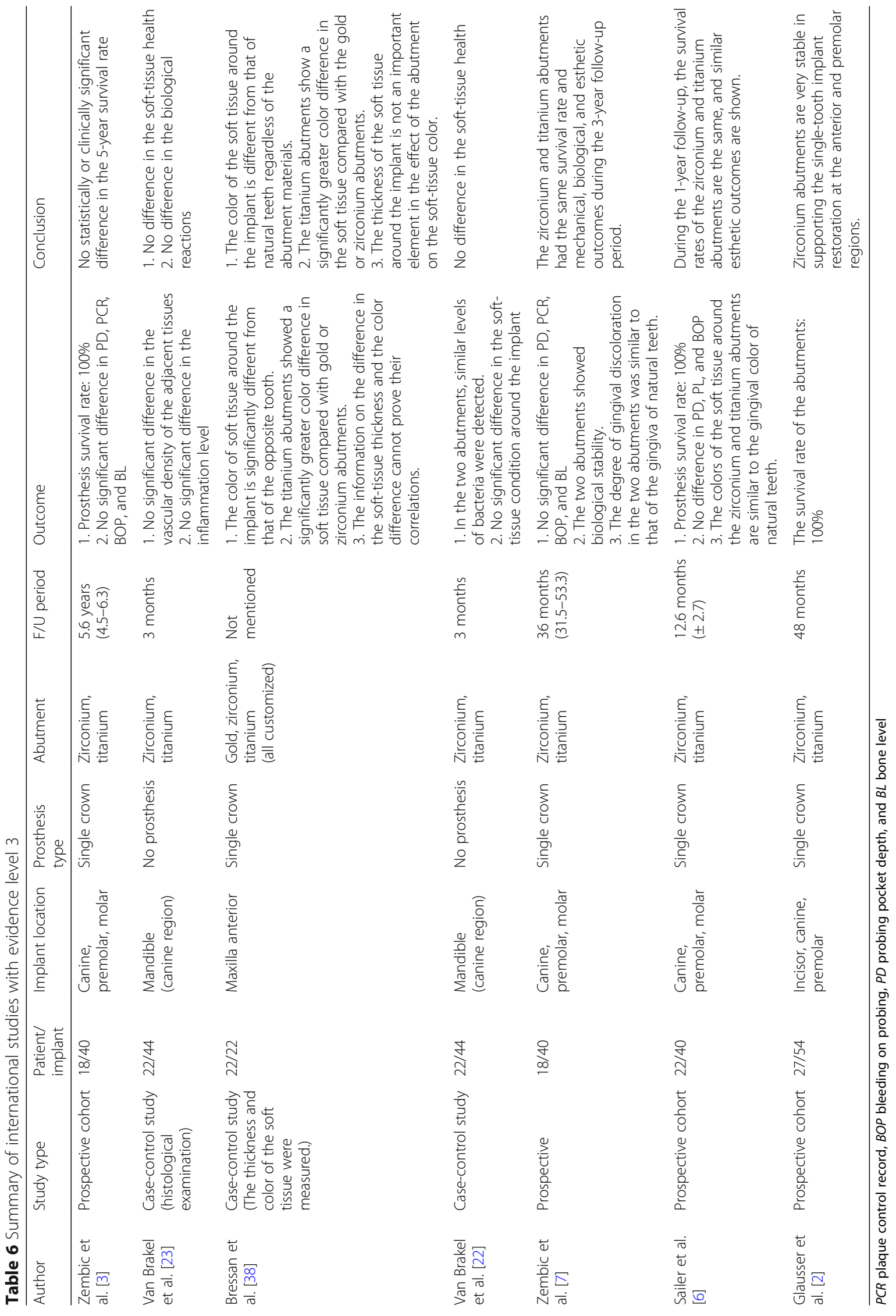


Table 7 Summary of international studies with evidence level 4

\begin{tabular}{|c|c|c|c|c|c|}
\hline Author & $\begin{array}{l}\text { Study type } \\
\text { (no. of samples) }\end{array}$ & $\begin{array}{l}\text { Implant } \\
\text { location }\end{array}$ & Abutment & F/U period & Outcome \\
\hline Lee et al. [24] & Case series (9) & $\begin{array}{l}\text { Maxilla } \\
\text { anterior }\end{array}$ & Zirconium abutment & $\begin{array}{l}52 \text { weeks after installing the } \\
\text { prosthesis }\end{array}$ & $\begin{array}{l}\text { Esthetic, no abutment fracture } \\
\text { or screw loosening }\end{array}$ \\
\hline Aydin et al. [25] & Case report (1) & $\# 22$ & Zirconium abutment & $\begin{array}{l}\text { Six months after installing } \\
\text { the prosthesis }\end{array}$ & $\begin{array}{l}\text { No difference in } P C R, B O P, P D \text {, } \\
\text { and } B L\end{array}$ \\
\hline Kalman et al. [26] & Case report (1) & $\# 22$ & $\begin{array}{l}\text { Customized zirconium abutment } \\
\text { (Nobel Procera) }\end{array}$ & Not mentioned & Esthetic \\
\hline Wadhwani et al. [27] & Case report (1) & $\# 12$ & $\begin{array}{l}\text { Customized abutment } \\
\text { (Straumann) }\end{array}$ & Not mentioned & Esthetic \\
\hline Mahn et al. [28] & Case report (1) & $\# 11$ & Customized abutment & Not mentioned & Esthetic \\
\hline Schneider et al. [29] & Case report (1) & \#21 & $\begin{array}{l}\text { Zirconium ART EASY abutment } \\
\text { (Thommen Medical) }\end{array}$ & Not mentioned & Esthetic \\
\hline Tan et al. [30] & Case report (1) & $\# 21$ & $\begin{array}{l}\text { Zirconium abutment ( } \\
\text { Astra Tech Inc., USA) }\end{array}$ & Not mentioned & $\begin{array}{l}\text { Customized titanium abutment: } \\
\text { excellent gingival contour, } \\
\text { gray shade in the gingival area; } \\
\text { zirconium abutment: no gray } \\
\text { shade in the gingival area }\end{array}$ \\
\hline
\end{tabular}

$P C R$ plaque control record, $B O P$ bleeding on probing, $P D$ probing pocket depth, and $B L$ bone level

prosthesis occur more than 5 years after, long-term studies lasting for more than 5 years are required. The analysis results of the domestic literature showed that zirconium abutments are mechanically, biologically, and esthetically stable, but most of the said literature have evidence level 4, meaning that the level of scientific evidence presented by them is low. Additionally, the stability of zirconium abutments is limited to the 5-year follow-up period. The evidence levels of international literature range from level 2 to level 4, and the scientific-evidence levels are higher and more varied compared to those of domestic literature. Like domestic literature, however, international literature reports the mechanical stability of zirconium abutments to last for 4 years; thus, the scientific evidence for the long-term stability of zirconium abutments is not sufficient. Further studies on the long-term survival rate of zirconium abutments are also required in other countries, and biological measurement values and esthetic outcomes need to be suggested using objective figures in long-term clinical practice.

Second, the domestic and international literature supporting the esthetic stability of zirconium abutments are case reports with a low evidence level, and most of them report the analysis results in a subjective language and have a short follow-up period or do not report the follow-up period. Among the domestic literature, three literature (written by Byeon et al. [31], Lee et al. [32], and Kim et al. [33], respectively) reported the follow-up period, and among the international literature, only two literature (written by Lee et al. [24] and Aydin et al. [25], respectively) reported the follow-up period. The rest of the literature did not mention the follow-up period. For the literature that reported the follow-up period, the maximum follow-up period was 52 weeks, and the average follow-up period was 6 months; thus, it is difficult to ensure esthetic stability. The outcomes were expressed in subjective language, only as "It is esthetic" or "It is stable," and no statistically significant objective data were provided. Therefore, the conclusion that zirconium abutments are preferred to titanium abutments for an esthetically superior outcome does not have sufficient scientific evidence. To provide a scientific basis for the esthetic stability of zirconium abutments, the gingival color change, etc. need to be expressed objectively through the standardization of figures, using a tool such as a spectrophotometer. The esthetic stability must be evaluated after a more than 5-year-long observation after prosthesis installation.

\section{Conclusions}

Zirconium abutments have a high survival rate regardless of implant location and prosthesis type within the 5-year follow-up period. Zirconium abutments are biologically stable. The evidence regarding the esthetic stability of zirconium abutments is not sufficient. Zirconium abutments are mechanically stable within the 5-year follow-up period. The long-term stability of zirconium abutments after 5 years cannot be determined. Therefore, clinical studies that investigate the long-term stability of zirconium abutments are required.

\section{Abbreviations}

BL: Bone level; BOP: Bleeding on probing; MFDS: Ministry of Food and Drug Safety, Republic of Korea; PCR: Plaque control record; PD: Probing pocket depth; RCTs: Randomized controlled trials

\section{Availability of data and materials}

Data sharing is not applicable to this article as no datasets were generated or analyzed during the current study. 


\section{Authors' contributions}

SB and BG participated in making the conception and design of the report and carried out the acquisition of data and drafting of literature. KJ, JW, and YH carried out the acquisition of data and made a final approval and guarantor of the manuscript. BE participated in making the conception and design of the report, carried out the acquisition of data, and made a final approval and guarantor of the manuscript. All authors read and approved the final manuscript.

\section{Ethics approval and consent to participate}

The study was reported to the Regional Ethical Committee. They found that the study did not require approval because it is a study of existing literature, not a human-related study, and does not use human-related materials for research.

\section{Consent for publication}

No person's data was used in this study.

\section{Competing interests}

The authors declare that they have no competing interests.

\section{Publisher's Note}

Springer Nature remains neutral with regard to jurisdictional claims in published maps and institutional affiliations.

\section{Author details}

'Department of Oral and Maxillofacial Surgery, Hallym University Sacred Heart Hospital, Anyang, South Korea. ${ }^{2}$ Department of Oral Implantology, Graduate School of Clinical Dentistry, Hallym University, Chuncheon, South Korea. ${ }^{3}$ Institute of Clinical Dentistry, Hallym University, Chuncheon, South Korea. ${ }^{4}$ Department of Dentistry, National Police Hospital, Seoul, South Korea. ${ }^{5}$ Department of Industrial Security, Hansei University, Gunpo, South Korea DDepartment of Dentistry, Hallym University Sacred Heart Hospital, 22 Gwanpyeong-ro 170 beon-gil, Dongan-gu, Anyang Gyeonggi-do 431-796, South Korea.

Received: 29 March 2018 Accepted: 2 August 2018

Published online: 10 September 2018

\section{References}

1. Kim HE, Cho IH (2013) Stress analysis and fatigue failure of prefabricated and customized abutments of dental implants. J Dent Rehab App Sci 29: 209-223

2. Glauser R, Sailer I, Wohlwend A, Studer S, Schibli M, Scharer P (2004) Experimental zirconia abutments for implant-supported single-tooth restorations in esthetically demanding regions: 4-year results of a prospective clinical study. Int J Prosthodont 17:285-290

3. Zembic A, Bosch A, Jung RE, Hammerle CH, Sailer I (2013) Five-year results of a randomized controlled clinical trial comparing zirconia and titanium abutments supporting single-implant crowns in canine and posterior regions. Clin Oral Implants Res 24:384-390

4. Canullo L (2007) Clinical outcome study of customized zirconia abutments for single-implant restorations. Int J Prosthodont 20:489-493

5. Nothdurft FP, Pospiech PR (2009) Zirconium dioxide implant abutments for posterior single-tooth replacement: first results. J Periodontol 80:2065-2072

6. Sailer I, Zembic A, Jung RE, Siegenthaler D, Holderegger C, Hammerle CH (2009) Randomized controlled clinical trial of customized zirconia and titanium implant abutments for canine and posterior single-tooth implant reconstructions: preliminary results at 1 year of function. Clin Oral Implants Res 20:219-225

7. Zembic A, Sailer I, Jung RE, Hammerle CH (2009) Randomized-controlled clinical trial of customized zirconia and titanium implant abutments for single-tooth implants in canine and posterior regions: 3-year results. Clin Oral Implants Res 20:802-808

8. Michael CG, Javid NS, Colaizzi FA, Gibbs CH (1990) Biting strength and chewing forces in complete denture wearers. J Prosthet Dent 63:549-553

9. Ferrario VF, Sforza C, Zanotti G, Tartaglia GM (2004) Maximal bite forces in healthy young adults as predicted by surface electromyography. J Dent 32:451-457

10. Cho JH. Effects of age and gender on maximal occlusal force and occlusal force distribution in Koreans: Korea University; 2006
11. Yoon H-R, Choi Y-J, Kim K-H, Chung C (2010) Comparisons of occlusal force according to occlusal relationship, skeletal pattern, age and gender in Koreans. Kor J Orthod 40:304-313

12. Kim YK, Kim SG, Yun PY, Hwang JW, Son MK. Prognosis of single molar implants: a retrospective study. Int J Periodontics Restorative Dent. 2010;30: 401-7.

13. Kim B, Jeong S, Chung K, Cho Y, Kwon H, Choi C (2009) Subjective food intake ability in relation to maximal bite force among Korean adults. J Oral Rehabil 36:168-175

14. Straumann Holding AG. Annual report 2013: turning a new page 2013: Available from: https://www.straumann.com/content/dam/media-center/ group/en/documents/annual-report/2013/STMN-2013-Annual-Report.pdf

15. Kim SS. (2011) Survival and complication rates of zirconia implant abutments supported for fixed partial dentures : a minimum 5 year followup study: Seoul National University;

16. Bae KH, Han JS, Seol YJ, Butz F, Caton J, Rhyu IC (2008) The biologic stability of alumina-zirconia implant abutments after 1 year of clinical senvice: a digital subtraction radiographic evaluation. Int J Periodontics Restorative Dent 28:137-143

17. de Medeiros RA, Vechiato-Filho AJ, Pellizzer EP, Mazaro JV, dos Santos DM, Goiato MC (2013) Analysis of the peri-implant soft tissues in contact with zirconia abutments: an evidence-based literature review. J Contemp Dent Pract 14:567-572

18. Guess PC, Att W, Strub JR (2012) Zirconia in fixed implant prosthodontics. Clin Implant Dent Relat Res 14:633-645

19. Gomes AL, Montero J (2011) Zirconia implant abutments: a review. Med Oral Patol Oral Cir Bucal 16:e50-e55

20. Nakamura K, Kanno T, Milleding P, Ortengren U (2010) Zirconia as a dental implant abutment material: a systematic review. Int J Prosthodont 23:299-309

21. Linkevicius T, Apse P (2008) Influence of abutment material on stability of peri-implant tissues: a systematic review. Int J Oral Maxillofac Implants 23: $449-456$

22. van Brakel $R$, Cune MS, van Winkelhoff $A J$, de Putter $C$, Verhoeven JW, van der Reijden W (2011) Early bacterial colonization and soft tissue health around zirconia and titanium abutments: an in vivo study in man. Clin Oral Implants Res 22:571-577

23. van Brakel R, Meijer GJ, Verhoeven JW, Jansen J, de Putter C, Cune MS (2012) Soft tissue response to zirconia and titanium implant abutments: an in vivo within-subject comparison. J Clin Periodontol 39:995-1001

24. Lee CY, Hasegawa H (2008) Immediate load and esthetic zone considerations to replace maxillary incisor teeth using a new zirconia implant abutment in the bone grafted anterior maxilla. J Oral Implantol 34:259-267

25. Aydin C, Yilmaz H, Bankoglu M (2013) A single-tooth, two-piece zirconia implant located in the anterior maxilla: a clinical report. J Prosthet Dent 109:70-74

26. Kalman L, Maclntosh K (2013) The use of pink porcelain to manage a malposed anterior implant: case report. J Can Dent Assoc 79:d117

27. Wadhwani $\mathrm{CP}$, Pineyro A, Akimoto K (2012) An introduction to the implant crown with an esthetic adhesive margin (ICEAM). J Esthet Restor Dent 24:246-254

28. Mahn DH, Polack MA (2009) Esthetic rehabilitation of maxillary incisors in conjunction with flapless surgical techniques, an implant zirconia crown, and porcelain veneers. J Esthet Restor Dent 21:294-302

29. Schneider R (2008) Implant replacement of the maxillary central incisor utilizing a modified ceramic abutment (Thommen SPI ART) and ceramic restoration. J Esthet Restor Dent 20:21-27 discussion 8

30. Tan PL, Dunne JT Jr (2004) An esthetic comparison of a metal ceramic crown and cast metal abutment with an all-ceramic crown and zirconia abutment: a clinical report. J Prosthet Dent 91:215-218

31. Byun SG, Na YC, Choi BR, Seo JM, Park HK (2013) A single maxillary anterior immediate implant restoration by trauma. J Dent Imp Res 32:17-21

32. Lee GJ, Choi BH, Kim HJ, Jung SM (2012) Immediate connection of customized zirconia abutment using flapless guided surgery: a clinical report. J Dent Rehabil Appl Sci 28:201-212

33. Kim US, Son SJ, Yang MY, Jang SW, You HM, Park DS et al (2011) Immediate implantation and restoration with CAD/CAM zirconia abutment after extraction of upper central incisors. J Kor Acad Esthet Dent 20:78-83

34. Kim SS, Yeo IS, Lee SJ, Kim DJ, Jang BM, Kim SH et al (2013) Clinical use of alumina-toughened zirconia abutments for implant-supported restoration: prospective cohort study of survival analysis. Clin Oral Implants Res 24:517-522

35. Kim JY, Seo JM (2014) Reconstruction of upper anterior by implant using customized zirconia abutment and all ceramics: a clinical report. J Dent Rehabil Appl Sci 30:81-92 
36. Byun SG, Kim YK, Park SC, Ju HE (2011) A single maxillary anterior implant restoration considering long term prognosis: case report. J Kor Acad Imp Dent 30:130-133

37. Yun HK, Ju HE, Kim YK, Park SC (2011) A single maxillary anterior immediate implant restoration. J Kor Acad Imp Dent 30:123-129

38. Bressan E, Paniz G, Lops D, Corazza B, Romeo E, Favero G (2011) Influence of abutment material on the gingival color of implant-supported all-ceramic restorations: a prospective multicenter study. Clin Oral Implants Res 22:631-637

Submit your manuscript to a SpringerOpen ${ }^{\circ}$ journal and benefit from:

- Convenient online submission

- Rigorous peer review

- Open access: articles freely available online

High visibility within the field

- Retaining the copyright to your article

Submit your next manuscript at $\boldsymbol{\nabla}$ springeropen.com 